\title{
Chorioptes texanus causing mange in goats: comparison of two therapeutic protocols
}

Chaithanya Chandran ${ }^{\star 1}$, Biju P. Habeeb ${ }^{2}$, O. K. Sindhu' ${ }^{2}$ A. Janus ${ }^{3}$, (i)

Citation: Chaithanya, C., Biju, P. H., Sindhu, O. K., Janus, A., Reghu Ravindran, Ajith Kumar, K.G. and Ajithkumar, S. 2021. Chorioptes texanus causing mange in goats: comparison of two therapeutic protocols. J. Vet. Anim. Sci. 52(4): 357-361 DOI: https://doi.org/10.51966/jvas.2021.52.4.357-361

Received: 17.02.2021

Accepted: 09.03.2021

Published: 15.12.2021

\section{Abstract}

Out of 34 caprine dermatological cases examined, 12 were detected positive for Chorioptes texanus. Pruritus, alopecia, crusts, thickening, wrinkling, cracks and fissures on legs, axillae, inguinal region and perineal region were the symptoms noticed in caprine chorioptic mange. In affected animals, reduction in haemoglobin concentration and per cent lymphocytes were noticed, along with elevation in the values of the total leukocyte count, per cent neutrophils and per cent monocytes. Values of serum glucose, zinc and copper were normal. All the 12 cases were treated with ivermectin at 10 days interval till two consecutive skin scrapings were negative for mites. In addition, all goats were treated with vitamin A supplements throughout the period. Six goats were treated topically with permethrin spray while other six animals were treated topically with lime sulphur spray. Both treatment protocols caused recovery of the animals from clinical symptoms, however, a skin scraping after 1 year revealed the presence of mites.

Keywords: Chorioptes spp., permethrin, lime sulphur

Running title: Chorioptes texanus mange: comparison of two protocols

Chorioptes spp. of mites infest cattle, horses, sheep and goats (Constable et al., 2017). They are transmitted by direct contact and contaminated fomites. They have a life span of 60 days and complete their life cycle on the body of host in three weeks (Smith and Sherman, 2009).

"Part of MVSc thesis of the first author submitted to Kerala Veterinary and Animal Sciences University, Pookode, Wayanad, Kerala

1. M.V.Sc. scholar, *Corresponding author, Mob. 8592858034. E mail: chandranchaithanya00@gmail.com

2. Assistant Professor

3. Assistant Professor, Department of Veterinary Epidemiology and Preventive Medicine

4. Associate Professor, Department of Veterinary Parasitology

5. Assistant Professor, Department of Veterinary Parasitology

6. Professor and Head, Department of Veterinary Clinical Medicine, Ethics and Jurisprudence

Copyright: (c) 2021 Chaithanya et al. This is an open access article distributed under the terms of the Creative Commons Attribution 4.0 International License (http://creativecommons.org/licenses/by/4.0/), which permits unrestricted use, distribution, and reproduction in any medium, provided the original author and source are credited. 
Two valid species of Chorioptes were reported previously viz., C. bovis and C. texanus (Lusat et al., 2011). The clinical signs of animals with chorioptic mange include alopecia, pruritus, thickening and wrinkling of the skin with scabs, crust and fissures on the feet and tail (Reddy et al., 2013). Severe infestation leads to decreased meat and milk production as well as poor hide quality, which may result in heavy economic loss in leather industry (Asmare et al., 2016).

\section{Materials and methods}

Goats presented at Teaching Veterinary Clinical Complex, Kerala Veterinary and Animal Sciences University, Pookode, with a history of skin lesions were selected for the study. Skin scrapings and scab materials from these animals were examined microscopically for the presence of mites. Complete blood count of infested goats was estimated by three part fully automated haematological analyzer (Mindray BC-2800Vet). Serum glucose was estimated by semiautomatic biochemical analyzer (Master T, Hospitex Diagnostics, Italy) with commercially available diagnostic kits (Biosystem diagnostics Pvt. Ltd), while serum zinc and copper were estimated using atomic absorption spectrophotometry (Perkin-Elmer, USA).

The infested goats were divided into Group I and Group II, consisting of six animals each. All animals were given inj. Ivermectin (Neomec $10 \mathrm{~mL}$ ) @ $200 \mu \mathrm{g} / \mathrm{kg} \mathrm{BW} \mathrm{S/C} \mathrm{at}$ 10 days interval until two consecutive skin scrapings became negative for mites. They were also given vitamin A supplements as Lavitone $\mathrm{H}$ injection @ $1 \mathrm{~mL} / 25 \mathrm{~kg} \mathrm{BW} / \mathrm{M}$ on the first day of treatment and continued the supplementation orally (Lvitone $\mathrm{H}$ liquid $5 \mathrm{~mL}$ daily) throughout the treatment period. The group I goats were treated topically with permethrin 0.05 per cent as spray (Durvet Permethrin 10 per cent) over the lesions once. Group II goats were treated with lime sulphur two per cent (Demoscanil 250 $\mathrm{mL}$ ) as spray over the lesions once. Response to treatment was evaluated clinically and treatment groups were compared based on the mite count per field in each review. Samples collected from six apparently healthy goats served as the control group. The data collected were statistically analyzed using SPSS version 24.0.

\section{Results and discussion}

Microscopic examination of skin scrapings revealed the presence of Chorioptes spp. in 12 out of 34 cases with skin lesions like hair loss and pruritus. The mites were small round, having cup shaped suckers on the short unjointed pedicel and distinctively round mouth parts as seen in Fig. 1 and Fig. 2. These characteristics were previously reported by Taylor et al. (2007). The length of the opisthosomal setae 1 and 2 of adult male were $49.57 \pm 2.14 \mu \mathrm{m}$ and $147.91 \pm 3.95 \mu \mathrm{m}$ respectively. Therefore, they were identified as C. texanus. Similar observations were previously recorded by Lusat et al. (2011). Chorioptes texanus was reported earlier in countries like Canada (domestic goats and raindeer), Israel (dairy cattle), Germany (cattle) and Korea (cattle). Caprine chorioptic mange was reported in India, by Reddy etal. (2013) and Dharanesha et al. (2015) in the states of Andhra Pradesh and Karnataka respectively. However, Reddy et al. (2013) did not identify the species of mite involved in the causation of the disease. Dharanesha et al. (2015) identified the mites as C. caprae in goats from Karnataka, based on the characters described by Soulsby (1982) and did not consider the length of opisthosomal setae for the species differentiation.

In the present study, the skin lesions were mainly observed on the legs ( 11 cases) and the axillae, inguinal region, perineal region, tail and ear (eight cases). The lesions of chorioptic mange in goats, most commonly appeared at the lower limbs (Smith and Sherman, 2009). In the present study, lesions at lower limbs were observed in 10 cases. Five out of 10 cases showed feet lesions. Dharanesha et al. (2015) observed the lesions of chorioptic mange in goats of Karnataka mainly on lips, muzzle, ears and periorbital areas and rarely around hoof, accessary claws and interdigital space. In the present study, main lesions observed were alopecia with crusting, erythema, thickening, wrinkling and erosions on the skin (Fig. 3). These lesions were previously reported by Reddy et al. (2013) and Jesse et al. (2016). 


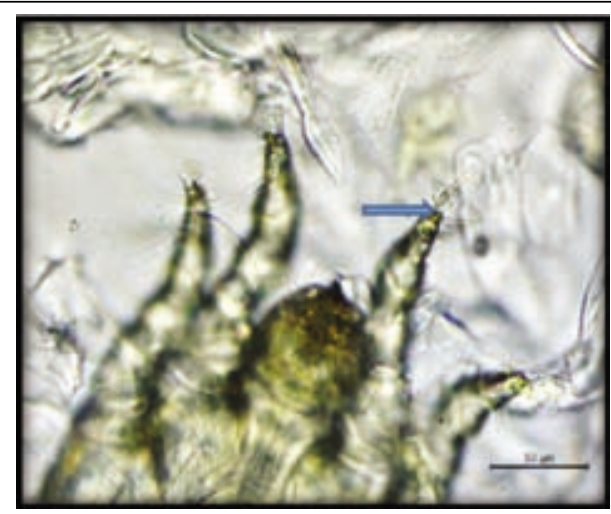

Fig. 1. C. texanus with cup shaped suckers on unsegmented pedicel of first and second pairs of legs

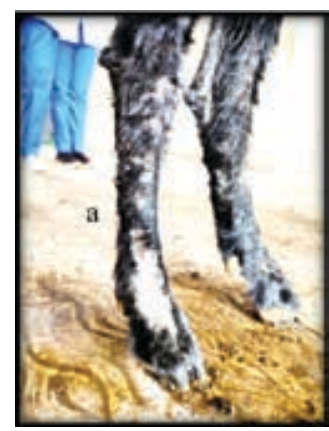

Fig. 3. Crusty alopecia on limbs
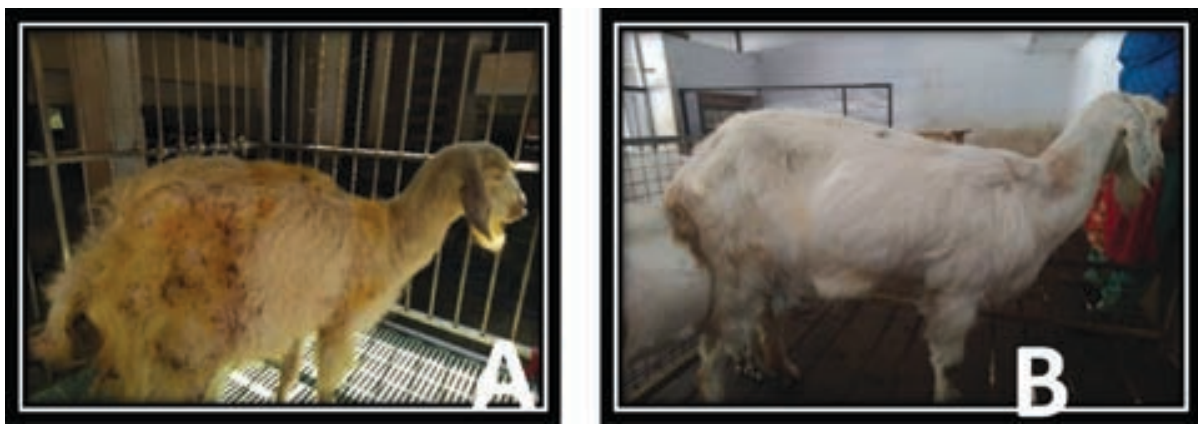

Fig. 4. Group I; A- Before treatment; B- After treatment
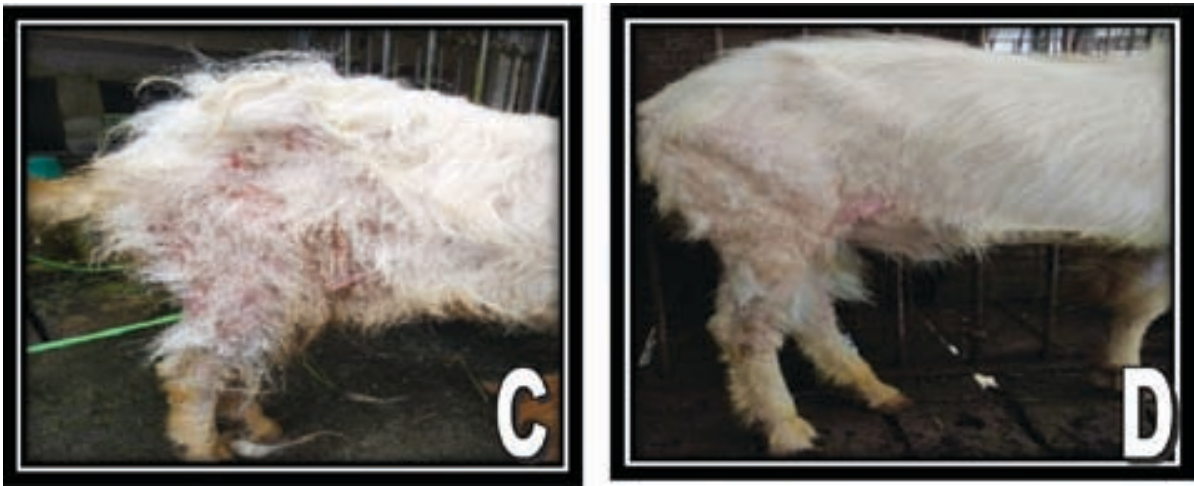

Fig. 5. Group II; C- Before treatment; D- After treatment 
In the present study, haemogram of the infested goats revealed lower mean haemoglobin concentration and per cent lymphocytes compared to healthy goats. Total leukocyte count and per cent neutrophils, monocytes revealed significant increase compared to control group (Table1). These observations were also noted by Marimuthu et al. (2015).

The infested animals did not show any significant changes in the serum zinc, copper and glucose concentrations compared to the control group (Table 2).

Animals treated topically with permethrin or lime sulphur were clinically normal by 20-40 days after the initial treatment. The reduction of mite count in group I and group II were similar (Table 3). Anaemia, neutrophilia, monocytosis and lymphocytopenia observed prior to the treatment in the infested goats became normal at the end of treatment. Serum zinc and copper concentrations after treatment

Table 1. Comparison of haemogram of goats infested with $C$. texanus before and after treatment

\begin{tabular}{|c|c|c|c|c|c|c|}
\hline \multirow{2}{*}{$\begin{array}{l}\text { SI. } \\
\text { No }\end{array}$} & \multirow[b]{2}{*}{ Parameters } & \multirow{2}{*}{$\begin{array}{l}\text { Uninfested } \\
\text { goats }(n=6)\end{array}$} & \multicolumn{2}{|c|}{ Group I $(n=6)$} & \multicolumn{2}{|c|}{ Group II $(n=6)$} \\
\hline & & & \begin{tabular}{c|} 
Before \\
treatment
\end{tabular} & $\begin{array}{c}\text { After } \\
\text { treatment }\end{array}$ & $\begin{array}{c}\text { Before } \\
\text { treatment }\end{array}$ & After treatment \\
\hline 1 & $\mathrm{Hb}(\mathrm{g} / \mathrm{dL})$ & $9.63 \pm 0.29$ & $\begin{array}{c}7.98 \pm 0.88 \\
n s\end{array}$ & $9.38 \pm 0.97$ & $\begin{array}{c}8.02 \pm 0.34 \\
n s\end{array}$ & $\begin{array}{c}8.93 \pm 0.53 \\
n s\end{array}$ \\
\hline 2 & VPRC (\%) & $28.12 \pm 0.84$ & $\begin{array}{c}25.02 \pm 2.33 \\
n s\end{array}$ & $28.65 \pm 2.76$ & $23.77 \pm 1.68$ & $\begin{array}{c}27.37 \pm 1.34 \\
n s\end{array}$ \\
\hline 3 & TEC $\left(\times 10^{6} / \mu \mathrm{L}\right)$ & $15.96 \pm 0.47$ & $\underset{n s}{13.91 \pm 1.19}$ & $\begin{array}{c}16.7 \pm 1.77 \\
n s\end{array}$ & $\begin{array}{c}14.61 \pm \\
n s\end{array}$ & $16.63 \pm 1.23$ \\
\hline 4 & $\operatorname{TLC}\left(\times 10^{3} / \mu \mathrm{L}\right)$ & $12.22 \pm 0.55$ & $\begin{array}{c}15.93 \pm 2.2 \\
n s\end{array}$ & $\begin{array}{c}14.97 \pm 2.85 \\
n s\end{array}$ & $\begin{array}{c}16.32 \pm 1.56 \\
n s\end{array}$ & $\begin{array}{c}13.13 \pm 0.68 \\
n s\end{array}$ \\
\hline 5 & Neutrophils (\%) & $35.83 \pm 0.6$ & $\begin{array}{c}45.5 \pm 3.17 \\
n s\end{array}$ & $\begin{array}{c}40.5 \pm 3.22 \\
n s\end{array}$ & $\begin{array}{c}44 \pm 2.72 \\
n s\end{array}$ & $35.67 \pm 0.62$ \\
\hline 6 & Lymphocytes (\%) & $62.33 \pm 0.88$ & $45.67_{\star \star} \pm 3.12$ & $\begin{array}{c}56.33 \pm 3.42 \\
n s\end{array}$ & $50.33_{\star \star} \pm 1.91$ & $61.83_{\star \star} \pm 0.7$ \\
\hline 7 & Monocytes (\%) & $0.33 \pm 0.21$ & $3.17_{\star \star \star} 0.6$ & $0.83_{\star \star \star}^{ \pm 0} 0.17$ & $0.83_{\star \star \star}^{ \pm 0} 0.31$ & $\begin{array}{c}0.5 \pm 0.22 \\
n s\end{array}$ \\
\hline 8 & Eosinophils (\%) & $\begin{array}{c}1.5 \pm 0.22 \\
n s\end{array}$ & $\begin{array}{c}5.83 \pm 2.32 \\
n s\end{array}$ & $\begin{array}{c}2.33 \pm 0.21 \\
n s\end{array}$ & $\begin{array}{c}4.83 \pm 1.35 \\
n s\end{array}$ & $\begin{array}{c}2.00 \pm 0 \\
n s\end{array}$ \\
\hline
\end{tabular}

** Significant at 0.01 level $(P<0.01)$; ${ }^{*}$ Significant at 0.05 level $(P<0.05)$; ns Non-significant $(P>0.05)$

Table 2. Comparison of serum biochemical parameters of goats infested with $C$. texanus before and after treatment

\begin{tabular}{|c|c|c|c|c|c|c|}
\hline \multirow[b]{2}{*}{$\begin{array}{l}\text { SI. } \\
\text { No }\end{array}$} & \multirow[b]{2}{*}{ Parameters } & \multirow{2}{*}{$\begin{array}{l}\text { Uninfested } \\
\text { goats }(n=6)\end{array}$} & \multicolumn{2}{|c|}{ Group I (n=6) } & \multicolumn{2}{|c|}{ Group II $(n=6)$} \\
\hline & & & $\begin{array}{c}\text { Before } \\
\text { treatment }\end{array}$ & $\begin{array}{c}\text { After } \\
\text { treatment }\end{array}$ & $\begin{array}{c}\text { Before } \\
\text { treatment }\end{array}$ & After treatment \\
\hline 1 & Glucose (mg/ dL) & $76.34 \pm 5.75$ & $\begin{array}{c}86.8 \pm 10.38 \\
n s\end{array}$ & $\begin{array}{c}81.99 \pm 12.36 \\
n s\end{array}$ & $\begin{array}{c}93.78 \pm 7.41 \\
\mathrm{~ns}\end{array}$ & $\begin{array}{c}93.22 \pm 5.68 \\
n s\end{array}$ \\
\hline 2 & Zinc $(\mu \mathrm{g} / \mathrm{dL})$ & $\begin{array}{c}132.57 \pm \\
34.64\end{array}$ & $\begin{array}{c}92.03 \pm \\
32.19 \\
\star \star\end{array}$ & $\begin{array}{c}154.23 \pm \\
22.08 \\
\text { ns }\end{array}$ & $\begin{array}{c}68.79 \pm \\
10.63 \\
\star \star\end{array}$ & $\underset{*}{128.67 \pm 14.59}$ \\
\hline 3 & Copper ( $\mu \mathrm{g} / \mathrm{dL})$ & $45.92 \pm 5.32$ & $\begin{array}{c}44.5 \pm 8.46 \\
n s\end{array}$ & $\begin{array}{c}55.56 \pm 7.68 \\
n s\end{array}$ & $\begin{array}{c}45.08 \pm 6.72 \\
\mathrm{~ns}\end{array}$ & $\begin{array}{c}66.08 \pm 7.09 \\
*\end{array}$ \\
\hline
\end{tabular}

** Significant at 0.01 level $(P<0.01)$; ${ }^{*}$ Significant at 0.05 level $(P<0.05)$; ns Non-significant $(P>0.05)$

Table 3. Comparison of mite count between Group I and Group II goats

\begin{tabular}{|c|c|c|c|}
\hline Day & $\begin{array}{c}\text { Group I } \\
(\mathbf{n}=\mathbf{6})\end{array}$ & Group II $(\mathbf{n}=\mathbf{6})$ & Z-value \\
\hline $\mathbf{0}^{\text {th }}$ day & $2.83 \pm 0.40$ & $2.17 \pm 0.54$ & $0.989^{\text {ns }}$ \\
\hline $\mathbf{1 0}^{\text {th }}$ day & $1.00 \pm 0.37$ & $0.50 \pm 0.34$ & $1.042^{\text {ns }}$ \\
\hline Z-value & $2.333^{*}$ & $2.232^{*}$ & \\
\hline
\end{tabular}

* Significant at 0.05 level $(p<0.05)$; ns Non-significant $(p>0.05)$ 
were increased, indicating the adequate nutritional anti -oxidant level in the body and health of the integumentary system.

Jesse et al. (2016) observed persistence of lesions even after the injection with ivermectin @ $200 \mu \mathrm{g} / \mathrm{kg} \mathrm{BW} \mathrm{S/C} \mathrm{for} \mathrm{three}$ weeks. Therefore, they continued the treatment with amitraz bath for three weeks and lesions were resolved. Hence, it was postulated that the systemic injection with ivermectin alone is not at all effective in the treatment of chorioptic mange and the use of topical acaricidal agents along with inj. ivermectin was suggested (Jesse et al., 2016).

In the present study, both treatment protocols caused recovery of the clinical symptoms of caprine chorioptic mange (Fig. 4 and Fig.5). However, a skin scraping after 1 year revealed the presence of mites in the goat treated with permethrin.

\section{Conclusion}

From the microscopical examination of skin scrapings of infected goats the aetiology of caprine chorioptic mange was identified as $C$. texanus based on their morphological characters. It was the first report of $C$. texanus in goats of Kerala. Chorioptes are generally having small round body and unsegmented pedicel with cup shaped suckers. The $C$. txanus are having short opisthosomal setae 1 and long setae 2. In the present study, crusty erythematous alopecia was noted predominantly on the lower legs. Reduction in haemoglobin concentration and per cent lymphocytes along with elevation in the values of the total leukocyte count, per cent neutrophils and per cent monocyte were observed in affected goats. Values of serum glucose, zinc and copper were normal. Topical application of permethrin or limesulphur along with parenteral ivermectin and vitamin A supplements are equally effective for the therapeutic management of caprine chorioptic mange.

\section{Conflict of interest}

The authors declare that they have no conflict of interest.

\section{References}

Asmare, K., Abebe, R., Sheferaw, D., Krontveit, R.I. and Barbara, W. 2016. Mange mite infestation in small ruminants in Ethiopia: Systematic review and metaanalysis. Vet. Parasitol. 218: 73-81.

Constable, P. D., Hinchcliff, K.W., Done, S.H. and Grunberg, W. 2017. Veterinary medicine: a textbook of the diseases of cattle, horses, sheep, pigs and goats. $\left(11^{\text {th }}\right.$ Ed.) Elsevier, St. Louis, Missouri. $2358 p$.

Dharanesha, N. K., Ananda, K. J., Cyrus, J., Lakkundi, J. N., Giridhar, P. and Venkatesh, M. D. 2015. An outbreak of chorioptic mange on goat in a farm at Gulbarga district, Karnataka, India. Indian Vet. J. 92: 35-38.

Jesse, F. F. A., Hambali, I.U., Abba, Y., Sadiq, M. A., Bitrus, A. A., Chung, E. L. T., Lila, M. A. M., Haron, A.W. and Saharee, A. A. 2016. Therapeutic options in management of a clinical case of Chorioptic mange in a goat. Res. J. Vet. Pract. 4: 39-41.

Lusat, J., Bornstein, S. and Wall, R. 2011. Chorioptes mites: re-evaluation of species integrity. Med. Vet. Entomol. 25 : 370-376.

Marimuthu, M., Abdullah, F. F. J., Mohammed, K., Adamu, L., Tijjani, A., Abba, Y., Sadiq, M. A., Ting, L. Y., Saharee, A. A. and Haron, A. W. 2015. Comparative treatment approach for Sarcoptes and Psoroptes mite infestation in a Boer cross. J. Adv. Vet. Anim. Res. 2: 84-88.

Reddy, B.S., Sivajothi, S. and Raju, K.G. 2013. Chorioptic mange and its therapeutic management in caprines. Intas Polivet. 14: 329-330.

Smith, M.C. and Sherman, D.M. 2009. Goat Medicine. (2nd Ed.). Wiley-Blackwell, lowa, 871p.

Soulsby, E.G. (1982) Helminthes, arthropods, and protozoa of domesticated animals. ( $7^{\text {th }}$ Ed.) Bailer Tindall, Philadelphia, 810p.

Taylor, M.A., Coop, R. L. and Wall, R. L. 2007. Vet Parasitol. (3 ${ }^{\text {rd }}$ Ed.) Blackwell, Oxford, 600 . 